\title{
Effects of seasons on some physiological parameters in Karya sheep
}

\author{
Tufan Altın ${ }^{1}$, Murat Yılmaz ${ }^{1 *}$, Funda Kıral ${ }^{2}$ and Elif Yorulmaz ${ }^{3}$ \\ ${ }^{1}$ Department of Animal Science, Faculty of Agriculture, Adnan Menderes University, Aydın \\ ${ }^{2}$ Department of Biochemistry, Faculty of Veterinary Medicine, Adnan Menderes University Aydın \\ ${ }^{3}$ The Association of Breeding Cattle Breeders, Aydin
}

\begin{tabular}{|l|l|}
\hline Article history & Abstract \\
Received: $18 \mathrm{Mar}, 2016$ & $\begin{array}{l}\text { Thermal stress redistributes the body resources including protein and energy at the cost } \\
\text { of decreased growth, reproduction, production and health. In this study, seasonal } \\
\text { Revised: } 10 \mathrm{Apr}, 2016 \\
\text { Accepted: } 16 \mathrm{Apr}, 2016 \\
\text { variations of body temperature, heart and respiratory rates, and level of serum cortisol } \\
\text { and cholesterol were investigated in Karya sheep. Heart rate was significantly higher } \\
(\mathrm{P}<0.05) \text { in winter and significantly low }(\mathrm{P}<0.05) \text { summer. The respiration rate was } \\
\text { significantly higher }(\mathrm{P}<0.05) \text { in summer and significantly }(\mathrm{P}<0.05) \text { low in winter. } \\
\text { Similarly, body temperature was significantly higher }(\mathrm{P}<0.05) \text { low in spring and } \\
\text { summer. Serum cholesterol and cortisol increase significantly }(\mathrm{P}<0.05) \text { during } \\
\text { summer. The studied parameters in Karya sheep may provide a baseline data for the } \\
\text { future studies. } \\
\text { Keywords: Sheep; physiological parameters; cortisol; cholesterol }\end{array}$
\end{tabular}

To cite this article: Altın T, M Yılmaz, F Kıral and E Yorulmaz, 2016. Effects of seasons on some physiological parameters in Karya sheep. Res. Opin. Anim. Vet. Sci., 6(3): 89-95.

\section{Introduction}

Tropical regions are characterized by high levels of solar radiation and environmental temperature which may adversely affect animal production (Castanheira et al., 2010; Alhidary and Abdelrahman, 2016). Environmental factors affecting the animals' survival activities and their productivity are extremely various. It is a concrete reality that providing a change in climatic conditions in a desired way is almost impossible. However, it is possible to take some measures to reduce any adverse effects of the conditions on animals. Temperature, thought to be rated in the first place among climatic conditions, is directly effective on the animals' performance. The thermal comfort zone for sheep ranges from 15 to $30^{\circ} \mathrm{C}$, and the critical temperature is above $35^{\circ} \mathrm{C}$ (Baêta and Souza, 2010). Divergences from this range upward or downward start to create problems to some extent. In general, high temperatures are more effective than low temperatures. The effect of high temperature is also related to another climatic factor, the relative humidity. Being kept in conditions beyond normal rates creates stress in animals. Different stress factors lead to a change in homeostasis and metabolism, and affect the productivity of the animals (Cengiz and Yalcin, 2001). The stress on animals created by changing weather conditions could be defined in different ways. In these definitions, rectal temperature, respiratory rate, and heart rate are the most common physiological parameters.

In this study, physiological changes in the sheep due to seasonal conditions were examined in Karya (Chios x Kivircik crossbred) sheep. For this purpose, seasonal changes of body temperature, heart rate and respiratory rate, and serum cortisol and cholesterol levels were investigated.

*Corresponding author: Murat Y1lmaz, Adnan Menderes University Faculty of Agriculture, Department of Animal Science, Aydin-Turkey; E-mail: myilmaz@ adu.edu.tr; Tel.: +90 2567727023 


\section{Materials and Methods}

\section{Animals}

This study was conducted on total 24 Karya (Kivircik x Chios Cross Breed) sheep, 16 ewes and 8 rams, having average 10 months. Neither the ewes nor the males had had any mating activities beforehand. Through the study period, the animals were kept in a half-covered sheep pen. During the study, food and water were provided ad libitum. They were tried to be grazed throughout the year as much as the conditions were suitable.

\section{Temperature and humidity measurement}

By means of a Hobo U12 model device fixed in the pen, the data on ambient temperature and relative humidity was recorded throughout the year. In addition to these, Temperature-Humidity Index (THI) was calculated according to the equation below, using the average temperature and relative humidity values at the pre-mentioned time zones (Marai et al., 2007):

$\mathrm{THI}=\mathrm{db}{ }^{\circ} \mathrm{C}-\left\{(0.31-0.31 \mathrm{RH})\left(\mathrm{db}{ }^{\circ} \mathrm{C}-14,4\right)\right.$

$\mathrm{db}=$ dry thermometer temperature $\left({ }^{\circ} \mathrm{C}\right), \quad \mathrm{RH}=$ Relative Humidity (\%) and is accepted that;

If $\mathrm{THI}<22.2$, then it means no thermal stress;

If $22.2<\mathrm{THI}<23.3$, then it means a moderate thermal stress;

If $23.3<\mathrm{THI}<25.6$, then it means a severe thermal stress.

If $25.6 \leq \mathrm{THI}$, then it means an extremely strong thermal stress.

\section{Experimental design}

The data were planned to be collected between $10^{\text {th }}$ and the $15^{\text {th }}$ days of September, January, April, and July. The winter season encountered a period in which the animals were in cold environmental conditions, the spring and the fall encounter periods in which they were in the comfort zone, and the summer encounters a period when the thermal strain was at the maximum level. In this frame, measurements related with rectal temperature, heart rates and respiratory rates were taken in the afternoon between 14.00 and 16.00 , and $10 \mathrm{ml}$ blood samples were taken from the jugular veins on each animal's neck. Heart and respiratory numbers were taken via a stethoscope. Rectal temperature was determined from the rectum using a digital thermometer.

\section{Blood samples and hormones assay procedure}

Blood samples were taken from the jugular vein and centrifuged at $3500 \mathrm{rpm}$ for 15 minutes. Serum was stored at $-20^{\circ} \mathrm{C}$ until analysis.

Commercial kits were used for the determination of cortisol (CSB-E17045Sh: Cusabio Biotech, China) and cholesterol (Archem A2091, Istanbul, Turkey) using a spectrophotometer (UV-1601, Shimadzu, Japan).

\section{Data analysis}

The statistical analyses of the above mentioned characteristics, by taking season, sex and live weight factors into consideration, were done according to Data Model, Repeated with Proc Mixed Procedure using R core team (2014).

\section{Results}

\section{Climatic data}

Regional study is under the effect of a Mediterranean climate. The summer is hot and dry, and winter is mild and rainy in this province. The data related to the temperature and relative humidity values in the pen on monthly base and on the days and at the times when the measurements were taken were summarized in Table 1.

As seen in Table 1, monthly average temperature in the pen was 4 or 5 degrees higher than the July averages given for Aydin for quite a long period (19602012) (DMI, 2013). When the temperature was evaluated together with the humidity, it is observed that the THI value in the fall, winter, and spring is not to create a thermal stress. However, it can be seen that THI in July in the summer is at a level to create extreme thermal stress (Marai et al., 2007)

\section{Physiological parameters}

As seen in Table 2, heart rate and the body temperature according to season changed quite significantly $(\mathrm{P}<0.01)$, as well as the respiratory rate significantly $(\mathrm{P}<0.05)$. The factors did not display a significant difference between the males and females. In this study, it was found that the average number of heart rate, respiration rate and body temperature were 114.56, 55.78 and 39.40 per minute respectively. According to the season, the lowest heart rate and the highest respiratory rate were observed in the summer.

\section{Serum cortisol and cholesterol levels}

The evaluation results related to the seasonal changes of the serum total cholesterol and cortisol levels are given in Table 3 .

In Karya yearlings, both cholesterol and cortisol levels showed differences according to seasons. During the summer season, the cholesterol and cortisol levels were significantly high. On the other hand, the lowest cortisol levels were in the falls, while there were not significant differences between the other seasons for cholesterol levels.

\section{Discussion}

One of the most significant findings in our study is that the heart rate was the lowest during the summer season while the respiratory rate was the highest. The 
reason for that was the fact that the animals exposed to high temperature during the summer season preferred to remain motionless which led to slower heart rate. The highest respiratory rate is the result of one of the bodycooling mechanisms of the animals. The respiratory rate is one of the physiological parameters displaying the

Table1: Climatic parameters in the research unit

\begin{tabular}{|c|c|c|c|c|c|}
\hline Seasons & Av.Temp. $\left({ }^{\circ} \mathrm{C}\right)$ & Min. Temp. $\left({ }^{\circ} \mathrm{C}\right)$ & Max. Temp. $\left({ }^{\circ} \mathrm{C}\right)$ & Av. Hum. (\%) & THI \\
\hline \multicolumn{6}{|l|}{ Fall } \\
\hline September & 17.8 & 6.7 & 27.4 & 56.9 & 17.2 \\
\hline Control Day & 12.6 & 7.2 & 18.4 & 55.7 & 12.8 \\
\hline Control Hour & 18.0 & - & - & 38.4 & 17.3 \\
\hline \multicolumn{6}{|l|}{ Winter } \\
\hline January & 7.4 & -2.0 & 15.5 & 73.3 & 8.0 \\
\hline Control Day & 8.5 & 7.6 & 9.7 & 81.6 & 8.9 \\
\hline Control Hour & 9.5 & - & - & 81.3 & 9.8 \\
\hline \multicolumn{6}{|l|}{ Spring } \\
\hline April & 18.8 & 8.7 & 31.2 & 61.7 & 18.2 \\
\hline Control Day & 16.7 & 12.2 & 23.0 & 68.9 & 16.5 \\
\hline Control Hour & 22.6 & - & - & 52.5 & 21.4 \\
\hline \multicolumn{6}{|l|}{ Summer } \\
\hline July & 32.4 & 21.8 & 42.8 & 43.8 & 29.2 \\
\hline Control Day & 33.9 & 24.3 & 41.1 & 33.1 & 29.8 \\
\hline Control Hour & 40.8 & - & - & 20.6 & 34.3 \\
\hline
\end{tabular}

Table 2: Descriptive statistics of physiological parameters and least square means

\begin{tabular}{|c|c|c|c|c|c|}
\hline \multirow[t]{11}{*}{ Least Square Means } & Classification & $\mathrm{N}$ & $\begin{array}{l}\text { Heart Rate } \\
\text { (Pulse/min) }\end{array}$ & $\begin{array}{l}\text { Respiration } \\
\text { (Breath/min) }\end{array}$ & $\begin{array}{c}\text { Body Temperature } \\
\left({ }^{\circ} \mathrm{C}\right)\end{array}$ \\
\hline & Sex & & & & \\
\hline & Male & 32 & $123.77 \pm 8.06$ & $63.84 \pm 9.27$ & $39.21 \pm 0.14$ \\
\hline & Female & 64 & $109.95 \pm 4.32$ & $51.74 \pm 4.96$ & $39.49 \pm 0.07$ \\
\hline & Season & & $* *$ & $*$ & $* *$ \\
\hline & Fall & 24 & $118.99 \pm 4.41^{b}$ & $54.57 \pm 5.07^{\mathbf{b c}}$ & $39.45 \pm 0.07^{\mathbf{b}}$ \\
\hline & Winter & 24 & $143.72 \pm 3.70^{\mathrm{a}}$ & $45.93 \pm 4.26^{c}$ & $39.65 \pm 0.06^{\mathrm{a}}$ \\
\hline & Spring & 24 & $114.28 \pm 4.88^{b}$ & $60.15 \pm 5.61^{\mathbf{a b}}$ & $39.21 \pm 0.08^{\mathrm{c}}$ \\
\hline & Summer & 24 & $90.45 \pm 6.94^{\mathbf{c}}$ & $70.52 \pm 7.98^{a}$ & $39.09 \pm 0.12^{\mathbf{c}}$ \\
\hline & Reg (lin.) & & & & \\
\hline & Live weight $(\mathrm{kg})$ & & $0.824 \pm 0.454$ & $0.945 \pm 0.522$ & $0.076 \pm 0.008$ \\
\hline \multirow[t]{5}{*}{ Descriptive Statistics } & Average & 96 & 114.56 & 55.78 & 39.40 \\
\hline & Minimum & 96 & 60.00 & 32.00 & 38.70 \\
\hline & Maximum & 96 & 168.00 & 160.00 & 40.40 \\
\hline & SD & 96 & 26.42 & 22.48 & 0.34 \\
\hline & VK $(\%)$ & 96 & 23.06 & 40.30 & 0.87 \\
\hline
\end{tabular}

*: $\mathrm{P}<0.05 ; * *: \mathrm{P}<0.01 ; \mathrm{a}, \mathrm{b}, \mathrm{c}$ : The difference among means carrying a different letter is significant. $(\mathrm{P}<0.05)$

Table 3: Descriptive statistics and the average least square means for serum total cholesterol and cortisol

\begin{tabular}{|c|c|c|c|c|c|}
\hline \multirow[t]{11}{*}{ Least Square Means } & Classification & $\mathrm{N}$ & Cholesterol (mg/dl) & $\mathrm{N}$ & Cortisol (ng/ml) \\
\hline & Sex & & & & \\
\hline & Male & 32 & $61.43 \pm 9.74$ & 31 & $376.13 \pm 35.66$ \\
\hline & Female & 64 & $80.75 \pm 5.22$ & 53 & $319.66 \pm 21.25$ \\
\hline & Season & & $*$ & & $* *$ \\
\hline & Fall & 24 & $62.98 \pm 5.33^{b}$ & 22 & $171.94 \pm 20.62^{d}$ \\
\hline & Winter & 24 & $61.74 \pm 4.48^{\mathbf{b}}$ & 22 & $308.89 \pm 16.28^{c}$ \\
\hline & Spring & 24 & $70.03 \pm 5.90^{b}$ & 21 & $384.68 \pm 22.15^{\mathbf{b}}$ \\
\hline & Summer & 24 & $89.60 \pm 8.39^{\mathrm{a}}$ & 19 & $526.05 \pm 30.40^{\mathrm{a}}$ \\
\hline & $\operatorname{Reg}(\operatorname{lin})$. & & & & \\
\hline & Live Weight (kg) & & $0.648 \pm 0.549$ & & $0.014 \pm 2.105 *$ \\
\hline \multirow[t]{5}{*}{ Descriptive Statistics } & Average & 96 & 74.31 & 84 & 337.06 \\
\hline & Minimum & 96 & 34.51 & 84 & 84.73 \\
\hline & Maximum & 96 & 148.80 & 84 & 620.14 \\
\hline & St. deviation & 96 & 25.01 & 84 & 125.39 \\
\hline & $\mathrm{VK}(\%)$ & 96 & 33.65 & 84 & 37.20 \\
\hline
\end{tabular}

*: $\mathrm{p}<0.05 ; * *: \mathrm{p}<0.01 ; \mathrm{a}, \mathrm{b}, \mathrm{c}, \mathrm{d}$ : The difference between the averages carrying different letters in a factor is significant ( $<<0.05)$. 
adaptation of the animals to the environment in which they live. When the animals are exposed to an environmental temperature over or below the comfort range, the first reaction they give is the increase in the respiratory rate (Koylu, 2009). Similarly, pulse rate, which is the reflection of the blood circulation, generally rises in high environmental temperature. This provides more heat to be removed from the body, increasing the flow of blood from the cells towards the surface in felt or unfelt ways. Pulse rate has sometimes been determined to have decreased due to a reduction in the speed of the metabolism in extremely high temperature (Marai et al., 2007). However, some other studies done have shown that high environmental temperature does not change the pulse rate (Koylu, 2009).

Ceyhan et al. (2006) found highly significant effects of month and time (morning and evening) on heart and respiratory rates and on the body temperature in a study they conducted on Kivircik, Black headed German Meat Sheep, $F_{1}$ (SBA x Kivircik and $\mathrm{G}_{1}$ (SBA $x F_{1}$ ) sheep. Marai et al. (2007) also compiled via different research findings that these characteristics changed due to seasons (summer and winter) and different times of the day (morning and afternoon). As for a study conducted on goats (Kayabasi, 2011), the effect of season on the same parameters was found significant in Cukurova Saanen and Balcali genotype yearling goats. Generally, the heart rates in the fall, winter, spring and summer seasons were 118.99; 143.72; 114.28; and 90.45 per minute respectively. It was interesting to measure the lowest heart rate in the summer and the highest in the winter. The heart rate generally increased in high environmental temperatures was stated by Marai et al. (2007) based on many research findings. However, in extremely high temperatures, it was also remarked in the same study that the heart rate could be diminished due to the reduction in the metabolic speed. Furthermore, Aharoni et al (2003) also proposed that the animals reduced their heart beats to reduce their heat load. In addition to these, there were also statements claiming that there was not a positive relation between the temperature and heart rate (Al-Haidary, 2004). Ceyhan et al. (2006) determined the highest heart rates in the winter season in a study they conducted on different genotypes. In this study, the researchers found heart rates 79.3 in January, 77.4 in April, 73.1 in July, and 72.5 in September. On the other hand, Kayabasi (2011) reported that heart rates were higher in June than in April and February in Cukurova Saanen and Balcali yearling goats. In Karya yearling sheep, the average heart rate per minute was found 114.56. Demiroren et al. (2002) found the heart rates as 92.50 in Tahirova sheep, 93.50 in Sakiz sheep; and 97.75 in Sonmez lambs under extreme temperature stress $\left(40-42^{\circ} \mathrm{C}\right)$. These results were in harmony with the results found for the summer season in our study. Ceyhan et al. (2006) reported that heart rates per minute were generally 78.6 in Kivircik sheep, 75.4 in Black Headed German Meat Sheep, 76.3 in $F_{1}(S B A x$ Kivircik sheep, and 77.4 in $\mathrm{G}_{1}\left(\mathrm{SBA} \times \mathrm{F}_{1}\right)$ sheep. Not only these estimations but also the values that Marai et al. (2007) compiled for different genotype sheep in different conditions are lower than the values found in this study. In Table 2, it can be seen that the respiratory rates per minute in the fall, winter, spring and summer are $54.57 ; 45.93 ; 60.15$; and 70.52 respectively, and that they reduce from the fall towards the winter, but increase in the spring and summer, and reach their climax in July. The seasonal change on the number of respiration was as expected and in harmony with the change in environmental temperature. It was observed that the more the ambient temperature raised, the more the respiration rate increased in the sheep in order to balance the thermal stress. Throughout the summer season, the thermal stress was characterized with the increased in the respiratory rate, and it was found to be higher in the summer in respect with the winter (Marai et al., 2007). Srikandakumar et al. (2003) reported that respiratory rate per minute in Omani and Australian Merino sheep increased in hot conditions and was 50 and 34 in December, and 128 and 65 in July. On the other hand, Ceyhan et al. (2006) found that respiratory rate in Kivircik, Black Headed German meat sheep, $\mathrm{F}_{1}$ (SBA x Kivircik) and $\mathrm{G}_{1}\left(\mathrm{SBA} \times \mathrm{F}_{1}\right)$ sheep was 81.5 breaths/min maximum in August, when the temperature was high and minimum 48.8 breaths/min in December, when the temperature was low. Kayabasi (2011) observed that the respiratory rate in Saanen yearling goats generally increased in February, April and June together with the increase in temperature. Respiratory rate was found to be $63.84 \mathrm{breath} / \mathrm{min}$ in male and 51.74 breaths/min in females. It can be said that respiratory rate was higher in males than in females even though the effect of sex on respiratory rate was insignificant. In Karya yearlings, respiratory rate per minute was 55.78. The average RR per minute in Tahirova and Sakiz sheep was measured as 58.8 and 65.1 respectively $\left(40-42^{\circ} \mathrm{C}\right.$ ambient temperature) by Demiroren et al. (2002). In Kivircik, Black Headed German meat sheep, $F_{1}$ (SBA x Kivircik), and $G_{1}$ (SBA $\mathrm{x} \mathrm{F}_{1}$ ) sheep quite similar values were determined like by Ceyhun et al. (2006).

In Karya yearlings, body temperature in the fall, winter, spring and summer was found as $39.45,39.65$, 39.21 , and $39.09^{\circ} \mathrm{C}$ respectively. It can be seen that the body temperature is high in the winter but low in the spring and summer. Ceyhan et al. (2006), as in this study, found the body temperature high in the winter and in the first months of the spring than in the summer 
months in their study. In contrast with the proposals above, Marai et al. (2007) reported that the rectal temperature was lower in the winter than in the summer months. Srikandakumar et al. (2003) determined the rectal temperature in Omani and Australian Merino sheep as 39.5 and $39.0^{\circ} \mathrm{C}$ respectively in December, and as 39.8 and $39.7^{\circ} \mathrm{C}$, respectively in July. They also emphasized that rectal temperature increased with the thermal stress. Kayabasi (2011) too determined that the rectal temperature rose in goats in the spring and summer seasons.

Generally, the average body temperature in Karya yearlings was found as $39.40^{\circ} \mathrm{C}$. Demiroren et al. (2002) recorded the rectal temperature in Tahirova, Sakiz and Sonmez genotypes as 39.81, 39. 97 and $40.30^{\circ} \mathrm{C}$, respectively at $39-40^{\circ} \mathrm{C}$ ambient temperature. Ceyhan et al. (2006) found the average body temperatures as $39.05,38.99,38.93$ and $39.03^{\circ} \mathrm{C}$ in Kivircik, Black Headed German meat sheep, $\mathrm{F}_{1}$ (SBA x Kivircik) and $\mathrm{G}_{1}\left(\mathrm{SBA} \times \mathrm{F}_{1}\right.$ ) sheep respectively. When the previously determined information for the rectal temperature ranging between $38.3-39.9^{\circ} \mathrm{C}$ in thermoneutral conditions (Marai et al. 2007), and the findings of the studies presented above were taken into account, it could be said that the obtained values were within the natural ranges. Karya sheep can be said to be able to keep their body temperatures in normal values even in high temperatures, and their thermal tolerance to be high.

When estimated in connection with the seasons, cholesterol and cortsol levels during the summer season were found significantly high in this study. This indicates an important exposure to high temperatures creating stress in the summer season. Cortisol is a reliable physiological index of stress in sheep. In cattle (King et al., 2006: Curley et al., 2008) and in sheep (Pajor et al., 2010), restless nervous animals have greater cortisol concentrations. These results suggest that more temperamental ewes had higher baseline cortisol concentrations (Pajor et al., 2010). The increase in the cortisol secretion in an animal is the best reaction that an animal gives to stress conditions. Cortisol secretion stimulates physiological mechanisms that will provide resistance to stress in the animal caused by hot conditions. Plasma cortisol level could increase in 20 minutes following the entrance into acute thermal stress, and could reach to its highest level in 2 hours. Cortisol increases over basal level, which is an indicator of having been exposed to a thermal load chronically, is the indicator of the animal's being in stress. On the other hand, in case of a decrease in the plasma cortisol activity under chronic thermal stress, it is accepted that the animal has adapted to stress factor (Silanikove, 2000). Even though the cortisol level is a useful physiological parameter to define acute stress in sheep, it is stated that it is not the same meaningful as that in defining chronic stress (Jaber et al., 2004). In order to define the reactions the animals performed against stress factors, such as changes in environmental temperature, being kept in cages, water restriction, and transport, serum cholesterol levels in biochemical parameters have also been the subject of some studies (Cengiz and Yalcin, 2001; Rajion et al., 2001; Nazifi et al., 2003; Jaber et al., 2004; Yokus et al., 2006; Casamassima et al., 2008). In a study conducted in the east of Turkey, blood cholesterol level in Sakiz x Ivesi crossbred sheep was found higher in September and July than in January and April (Yokus et al., 2006). An increase was noticed towards the summer for the fall. Nazifi et al. (2003) reported that in Fat-Tailed Iranian Sheep maintained in cold $\left(4^{\circ} \mathrm{C}\right)$, optimum $\left(21^{\circ} \mathrm{C}\right)$ and hot $\left(40^{\circ} \mathrm{C}\right)$ environments, cholesterol was $1.85,1.42$ and $1.46 \mathrm{mmol} / \mathrm{l}$, respectively, and cortisol was 16.56 , 10.76 and $19.32 \mathrm{mmol} / \mathrm{l}$ respectively, and that cortisol was high in cold conditions; however, cholesterol was high in both cold and hot conditions. Rasooli et al. (2010) found cortisol levels as 1.20 and 0.85 in the male yearlings kept in external conditions $\left(31-50^{\circ} \mathrm{C}\right)$ and in internal conditions $\left(26-32^{\circ} \mathrm{C}\right)$, and emphasized that the cortisol level increased at a significant rate from June till October in the animals particularly kept externally in a hotter environment. In a study conducted to define the effects of multiple stress factors (extreme temperature, provender shortage and walk) on Malpura Sheep (Sejian et al., 2013), cortisol level was reported to have risen. Pajor et al. (2013) found that an increased temperament score, through the higher cortisol concentration, has a great effect on the lambs' energy metabolic profile, which influences the fattening performance. Yokus et al. (2006) found in the east of Turkey that the cholesterol levels in September, January, April and July were 65.95, 55.86; 54.04 and $69.04 \mathrm{mg} / \mathrm{dl}$, respectively in Sakiz x Ivesi hybrid sheep and blood cholesterol level was 67.00; 55.58; 56.50 and $68.42 \mathrm{mg} / \mathrm{dl}$ in barren sheep in September and July.

\section{Conclusion}

The variation in heart rate according to the seasons was against the general expectations. This could be interpreted as the pulse rate could diminish in extremely high temperatures due to the decrease in metabolic speed. The respiratory rate was found higher in the summer, owing to the rise in temperature. Rectal temperature was found within the rates defined for sheep. It could be concluded that Karya type yearlings could maintain their body temperature in balance against the altering environmental temperatures and could adapt to changing seasonal conditions. Serum cholesterol and cortisol level were determined higher in the summer with respect to the other seasons. The result of this study could provide the baseline data for future research. 


\section{Acknowledgement}

The authors would like to thank to the financial support of Scientific Research projects Unit of Adnan Menderes University.

\section{References}

Aharoni Y, Brosh A, Kourilov P, Arieli A (2003) Thevariability of theratio of oxygen consumption to heart rate in cattle and sheep at different hours of the day and under different heat load conditions. Livest Prod Sci 79: 107-117.

Al-Haidary A (2004). Physiological Responses of Niamey sheep to heat stress challenge under semiarid environments. Inter J Agric Biol 6: 307-309.

Alhidary IA, Abdelrahman MM (2016) Effects of naringin supplementation on productive performance, antioxidant status and immune response in heat-stressed lambs. Small Rumin Res 138: 31-36.

Baêta FC, Souza CF (2010) Ambiência em edificações rurais: conforto animal. 2.ed. Universidade Federal de Viçosa, Viçosa, MG

Casamassima D, Pizzo R, Palazzo M, D’Alessandro AG, Martemucci G (2008). Effect of water restriction on productive performance and blood parameters in comisana sheep reared under intensive condition. Small Rum Res 78: 169-175.

Castanheira M, Paiva RS, Louvandini, H., Landim, A, Soares Fiorvanti MC, Dallago BS, Correa PS, Concepta McManus C (2010) Use of heat tolerance traits in discriminating between groups of sheep in central brazil. Trop Anim Health Prod 42: 1821-1828.

Cengiz F, Yalcın M (2001) Koyunlarda Metabolizma Kafesinde Tutulmanın Bazı Fizyolojik Parametreler Üzerine Etkileri. J Fac Vet Med 20: 59-63.

Ceyhan A, Kaptan C, Ada M, Erdoğan İ, Taluğ AM (2006). Kıvırcık Siyah Başlı Alman Et Koyunu, $(\mathrm{SBA} \times$ K1vircık) F1 ve $(\mathrm{SBA} \times \mathrm{F} 1) \mathrm{G} 1$ Koyunların Bandırma Çevre Koşullarına Fizyolojik Tepkileri. Ankara Üniversitesi Ziraat Fakültesi Tarım Bilimleri Dergisi 12(2): 113-120.

Curley Jr KO, Neuendorff DA, Lewis AW, Cleere JJ, Welsh Jr TH, Randel RD (2008) Functional characteristics of the bovine hypothalamicpituitary-adrenal axis vary with temperament. Horm Behav 53: 20-27.

Demiroren E, Taşkın T, Takma Ç (2002) The physiologic adaptation abilities of sheep and goats under excessive temperatures. Ege Üniversitesi Ziraat Fakültesi Dergisi 39 (2):79-86.

DMİ (2013) Fazio E, Manera M, Mignacca S, Medica P, Ferlazzo A (2013) Cortisol Changes in Pregnant and Post-Partum Ewes: Effects of
Single or Twin Births. Trends in Veterinary Sciences. Chapter 10, pp 51-54. http://www.dmi.gov.tr

Jaber LS, Habre A, Rawda N, Abi Said, M, Barbour, EK, Hamadeh, S (2004) The effect of water restriction on certain physiological parameters in Awassi sheep. Small Rumin Res 54: 115-120.

Kayabasi D (2011) Studies On the physiological responses related to seasonal variation in çukurova saanen and balcali goats under sub-tropical climate conditions. ÇÜ Fen ve Mühendislik Bilimleri Dergisi Y1l: 2012 Cilt: 28-1.

King DA, Schuehle Pfeiffer CE, Randel RD, Welsh Jr TH, Oliphint RA, Baird BE, Curley Jr KO, Vann RC, Hale DS, Savell JW (2006). Influence of animal temperament and stress responsiveness on the carcass quality and beef tenderness of feedlot cattle. Meat Sci 74: 546-556

Koylu MU (2009) A Research On Adaptation and Yield Of Improved Saanen Crossbred Goats Under Mersin Conditions. Master's thesis, ÇÜ Fen Bilimleri Enst, Adana.

Marai IFM, El-Darawany AA, Fadiel A, Abdel-Hafez MA (2007) Physiological traits as affected by heat stress in sheep-A review. Small Rumin Res 71: 112.

Nazifi S, Saeb M, Rowghani E, Kaveh K (2003) The influences of thermal stress on serum biochemical parameters of Iranian fat-tailed sheep and their correlation with triiodothyronine (T3), thyroxine (T4) and cortisol concentrations. Comp Clin Pathol 12: $135-139$.

Pajor F, Kovács A, Tőzsér J, Péter P (2013) The influence of temperament on cortisol concentration and metabolic profile in Tsigai lambs. Archiv Tierzucht 56(56): 573-580.

Pajor F, Murányi A, Szentléleki A, Tőzsér J, Póti P (2010) Effect of temperament of ewes on their maternal ability and their lambs' postweaning traits in Tsigai breed. Arch Tierz 53: 465-474.

R Core Team (2014) R: A Language and Environment for Statistical Computing. Available online at: http://www.R-project.org

Rajion MA, Mohamed Saat I, Zulkifli I, Goh YM (2001). The effect of road tranportation on somephysiological Stres Measures in Goats. AsianAust J Anim Sci 14(9): 1250-1252.

Rasooli A, Jalali MT, Nouri M, Mohammadianc B, Barati F (2010). Effects of chronic heat stress on testicular structures, serum testosterone and cortisol concentrations in developing lambs. Anim Rep Sci 117: 55-59.

Sejian V, Maurya VP, Kumar K, Naqvi SMK (2013). Effect of multiple stresses on growth and adaptive capability of Malpura ewes under semi-aridtropical environment. Trop Anim Health Prod 45: 107-116. 
Res. Opin. Anim. Vet. Sci., 2016, 6(3): 89-95.

Silanikove N (2000). Effects of heat stres on welfare of extensively managed Domestic Ruminants. Livest Prod Sci, 67: 1-18.

Srikandakurmar A, Johnson EG, Mahgoub O (2003) Effect of heat stres on respiratory rate, rectal temperature and blood chemistry in Omani and
Australian Merino Sheep. Small Rumin Res, 49: 193-198.

Yokus B, Çakır DU, Kanay Z, Gülten Uysal E (2006) Effects of Seasonal and Physiological Variations on the Serum Chemistry, Vitaminsand Thyroid Hormone Concentrations in Sheep. J Vet Med A 53: 271-276. 